Article

\title{
Spatial Patterns of Structural Complexity in Differently Managed and Unmanaged Beech-Dominated Forests in Central Europe
}

\author{
Katharina Willim ${ }^{1, *}{ }^{1}$, Melissa Stiers ${ }^{1}$, Peter Annighöfer ${ }^{2}$, Martin Ehbrecht ${ }^{1}$, \\ Christian Ammer ${ }^{1}$ (D) and Dominik Seidel ${ }^{1}$ (D) \\ 1 Faculty of Forest Sciences, Silviculture and Forest Ecology of the Temperate Zones, University of Göttingen, \\ 37077 Göttingen, Germany; melissa.stiers@forst.uni-goettingen.de (M.S.); mehbrec1@gwdg.de (M.E.); \\ Christian.Ammer@forst.uni-goettingen.de (C.A.); dseidel@gwdg.de (D.S.) \\ 2 Forest and Agroforest Systems, Technical University of Munich, 85354 Freising, Germany; \\ peter.annighoefer@tum.de \\ * Correspondence: kwillim1@forst.uni-goettingen.de; Tel.: +49-551-39-33679
}

Received: 5 May 2020; Accepted: 10 June 2020; Published: 12 June 2020

\begin{abstract}
One of the main goals of modern silviculture is to emulate the structural complexity of old-growth forests. In this context, it is of advantage to identify a target state of structural complexity at the stand level and to analyze the spatial characteristics that led to the desired complexity of forest structures in primary forest references. In this study, we used 3D forest scenes captured by terrestrial laser scanning (TLS) to identify spatial patterns of structural complexity of differently managed and unmanaged European forests dominated by beech (Fagus sylvatica L.). We scanned in managed even-aged and uneven-aged stands, as well as in formerly managed forests (National Parks) and primary forests. For three different forest strata, representing the understory, the midstory, and the overstory of a forest stand, we determined the structural complexity mathematically using fractal analysis. Beyond that, we analyzed the density, as well as the horizontal and vertical distribution of plant material. For all three forest strata, we observed differences in structural complexity between the different forest types. Within the lower and middle strata, the investigated primary forests showed a random to regular distribution of plant material, as well as a complex understory structure as a result of pronounced natural decay. Compared to the primary forests, the managed uneven-aged stands showed quite similar spatial patterns of distribution of plant material, but on average a higher space occupation in the lower and middle forest stratum. Our results suggest that single tree or group selection cutting is a useful management tool to imitate old-growth structures of undisturbed beech-dominated forests.
\end{abstract}

Keywords: stratification; canopy layer; box-dimension; Fagus sylvatica L.; primary forest; fractal analysis; terrestrial laser scanning; management gradient; Carpathian Biosphere Reserve

\section{Introduction}

Creating complex forest structures is one of the main objectives of modern forest management and is becoming increasingly popular, especially in Central Europe and North America [1-4]. This management goal is of interest, because structural complexity can be positively associated with several ecosystem services and functions [5,6], including biodiversity [7-9], forest productivity [2,10-12], nutrient cycling [13], and habitat heterogeneity [14]. A complex forest structure is also expected to support ecosystem stability, resilience, and adaptability towards changes in environmental conditions $[15,16]$. 
The few remaining primary forests that can be found in Central Europe are characterized by what is referred to as old-growth forest structure [17]. They combine structural attributes, such as dense natural regeneration, the presence of secondary crowns, and a high variation of crown structure that all result in complex spatial arrangements within the forest [18-21]. Considering the vertical and horizontal dimension, structural complexity manifests itself in multiple canopy layers and an irregular horizontal distribution of tree components, consisting of irregularly distributed canopy gaps and dense understory vegetation patches [14].

So far, in order to promote structural complexity, the management focus is more on uneven-aged, multi-layered forest stands, instead of even-aged, single-layered stands. In terms of enhancing the horizontal structure, the creation of differently sized and distributed canopy gaps proved to be an efficient management approach [4]. It is yet largely unknown whether these measures result in structures that are also typical for primary forests. In order to imitate complex structures of primary forests, we first need to make their characteristic structures measurable and reproducible. Despite approaches to quantify complexity without 3D measurements, such as the structural complexity index (SCI) [22], the mean information gain index (MIG) [23], or the arc-chord ratio (ACR) rugosity index [24], terrestrial laser scanning (TLS) has shown to be an efficient and effective method allowing for an accurate and precise assessment of three-dimensional forest structure [25-27]. In combination with methods for quantifying complexity, such as fractal analysis [28], the structural complexity of forests can be assessed mathematically. The approach can also be utilized to quantify the complexity of tree foliage [29], tree crowns [30-32], entire tree architecture [33,34] and stand structure [35,36] by using three-dimensional (3D) point clouds derived from TLS. Several studies used this approach to characterize and compare the structural complexity of European temperate forests along a management gradient [37-39]. Ehbrecht et al. [37] showed that forests with a high stand structural complexity are characterized by a high tree size differentiation, high diversity of tree diameters, and random patterns of tree spacing. Stiers et al. [39] found a significantly higher stand structural complexity in primary European beech forests than in formerly managed (20-30 years of no management) and presently managed beech stands.

While we are now able to quantify the structural complexity of forests, we still lack a clear picture of the spatial patterns of structural complexity at the stand level [40]. After identifying the target structural complexity at the stand level, e.g., by taking the structural complexity of an old-growth forest as a reference, it is also crucial to identify the structural characteristics of such a reference that resulted in a given complexity. This is because many different configurations of plant material in a forest may result in similar levels of structural complexity, but the forests may differ largely in where the key strata or zones of complexity can be found, e.g., complex understory versus complex overstory.

Therefore, it is important to not only quantify the level of stand structural complexity, but also to study the spatial arrangement of plant material that leads to a given structural complexity. From a management perspective, it is also important to know how structural complexity and its characteristics differ among differently managed forests, formerly managed forests, and primary forests. Therefore, the primary aim of this paper is to contribute to the understanding of spatial patterns of structural complexity in such forests. To do so, structural complexity needs to be quantified at the stand level but also for smaller entities. We calculated the box-dimension $\left(D_{b}\right)$ as an estimate of the fractal dimension for three different forest strata of 3D forest scenes, representing the under-, mid- and overstory of a forest stand. We analyzed the density, as well as the horizontal and vertical distribution of plant material, in order to examine spatial patterns of structural complexity. Specifically, the following research questions were addressed:

(i) Do differently managed beech-dominated forests differ in the complexity of their lower, middle, and upper forest stratum?

(ii) Are differences in the structural complexity of different forest strata characterized by differences in the density and distribution of plant material? 


\section{Materials and Methods}

\subsection{Study Sites}

We studied different European beech (Fagus sylvatica L.) forest sites in Germany, Slovakia, and the Ukraine. The location of all study sites can be found in Figure 1.

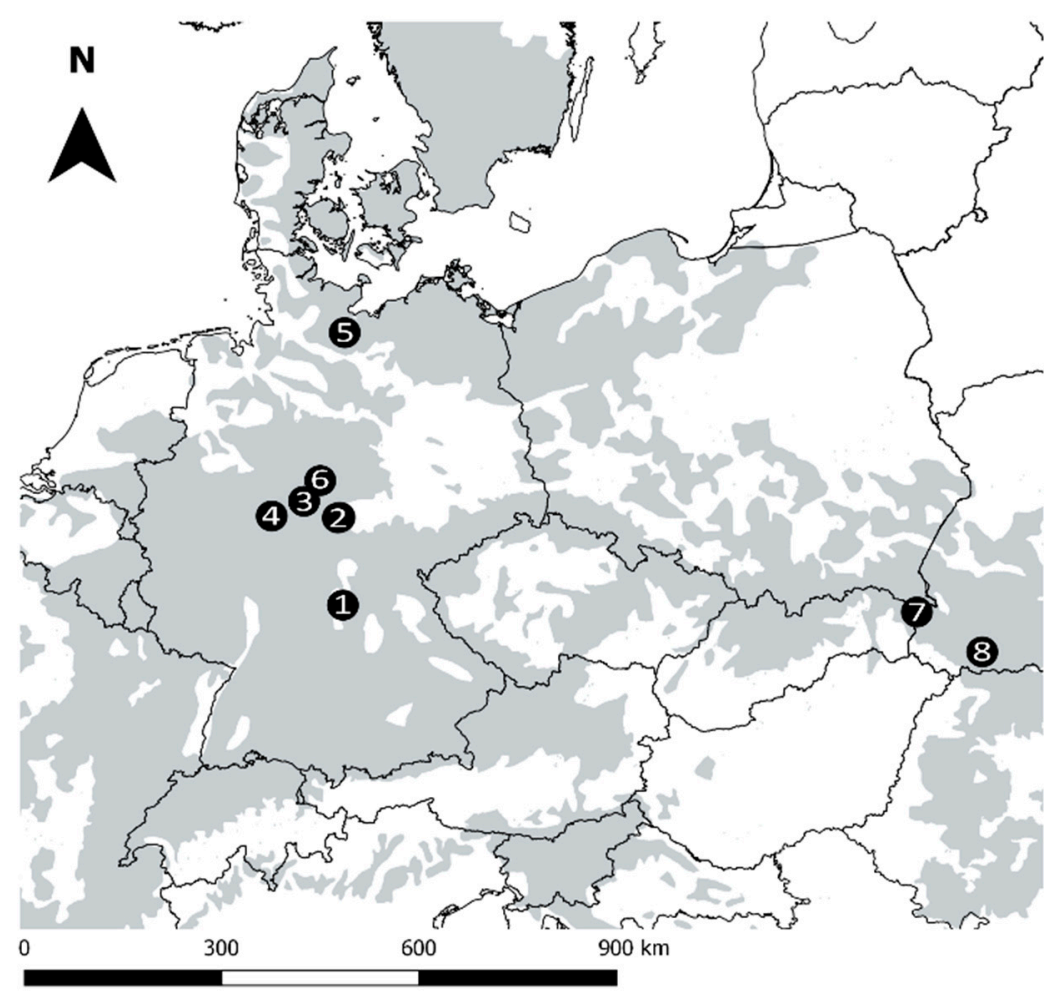

Figure 1. Natural distribution area of Fagus sylvatica L. in Central Europe (gray area) and location of the study sites. Each number represents one study site (1 = Ebrach, 2 = Hainich-Dün, $3=$ Hann. Münden, $4=$ Kellerwald, 5 = Lübeck, $6=$ Reinhausen, $7=$ Rožok and $8=$ Uholka. Source of species distribution map: http://www.euforgen.org. (modified after Willim et al. [38]).

All study sites were pure beech stands or beech-dominated stands with a minimum share of beech of $66 \%$ in basal area. The managed stands are in the developmental phase of mature timber and at least 81 years of age (see Table 1). We tried to figure out the documented ages of the managed and unmanaged stands. However, this was only possible in forest stands of the Biodiversity Exploratories, as well as for the managed stands in Ebrach, Hann. Münden, Lübeck and Reinhausen, where current data was available. In the formerly managed National Parks, we had information about the stand age at that time when management was ceased, e.g., 30 years ago. Therefore, it was possible to calculate the age during data collection. Only in the primary forests, we had to rely on estimates from other studies.

All our study sites have temperate climatic conditions after the Köppen Geiger classification [41]. Annual mean temperature varies between 6.0 and $8.0^{\circ} \mathrm{C}$. Annual precipitation ranges from 500 to 1407 mm. Except for Lübeck (40-90 m above sea level; abbreviation: a.s.l.), all study sites in Germany are located in the lower mountain ranges (190-1000 m a.s.1.). The study sites in the Western Carpathians are located highest, with 580-840 m (a.s.1). A detailed description of the environmental conditions of the study sites, as well as information about the number of plots per study sites are given in Table 1. 
Table 1. Information on the basic environmental conditions of the study sites (MAT = mean annual temperature; $\mathrm{MAP}=$ mean annual precipitation). For each study site, we chose four study plots. For the Hainich-Dün region, we considered additional study plots $\left({ }^{*}\right)$, which were part of the Biodiversity Exploratories. Number (No.) of study plots for each forest type were: even-aged (EA): $n=12$, uneven-aged (UEA): $n=8$, formerly managed (FM): $n=11$ and primary forest (PF): $n=8$.

\begin{tabular}{cccccccc}
\hline Location & Study Sites & $\begin{array}{c}\text { MAT } \\
\left({ }^{\circ} \mathbf{C}\right)\end{array}$ & $\begin{array}{c}\text { MAP } \\
(\mathbf{m m})\end{array}$ & $\begin{array}{c}\text { Elevation } \\
(\mathbf{m} \text { a.s.1.) }\end{array}$ & $\begin{array}{c}\text { Forest } \\
\text { Type }\end{array}$ & $\begin{array}{c}\text { Age } \\
\text { (Years) }\end{array}$ & $\begin{array}{c}\text { No. of } \\
\text { Plots }\end{array}$ \\
\hline Germany & Ebrach & $7-8$ & 850 & $320-480$ & UEA & 111 & 4 \\
& Hainich & $6.5-8$ & $500-800$ & $285-550$ & UEA & $160-186$ & $4^{*}$ \\
& Hann. & $6.5-7.5$ & $750-1050$ & $270-410$ & EA & 81 & 4 \\
& Münden & & & & & & \\
& Kellerwald & $6-8$ & $600-800$ & $540-635$ & FM & 184 & 4 \\
& Lübeck & $8-8.5$ & $625-725$ & $40-90$ & EA & 131 & 4 \\
Slovakia & Reinhausen & 8 & 740 & $190-310$ & EA & 98 & 4 \\
Ukraine & Rožok & $6-7$ & 780 & $580-745$ & PF & $\sim 220$ & 4 \\
\hline
\end{tabular}

The chosen forest sites represent different forest types in Central Europe. They consist of even-aged, uneven-aged, formerly managed, and unmanaged beech stands. Even-aged managed stands are located in the forest districts of Hannoversch Münden and Reinhausen (Lower Saxony State Forest). In these stands, management is based on the "Guidelines of beech forest management in Lower Saxony, Germany" [42]. This forest type is mainly characterized by a rather yield-orientated management. It is based on a thinning cycle of about five to 10 years. Around an age of 120 to 140 years, trees that have reached a certain target diameter are harvested [43]. Further, even-aged stands were selected in the forest districts of Lübeck (Northern German Lowlands). These stands are characterized by reduced thinning and harvesting frequencies and intensities, as well as by a high growing stock. Formerly managed beech stands were selected in the National Parks "Hainich" and "Kellerwald-Edersee". Both study sites underwent no management interventions for at least two to three decades [38]. In addition to the above-mentioned stands, we considered uneven-aged and formerly managed stands in the Hainich-Dün region (marked by a *, Table 1) that are part of the Biodiversity-Exploratories (www.biodiversity-exploratories.de), which is a long-term research project that aims at investigating the impacts of management on biodiversity and ecosystem processes [44]. Further uneven-aged stands were recorded in Ebrach (Bavaria). The management of the uneven-aged stands is characterized by single tree harvests of high frequency but low intensity [45]. Interventions are mainly focused on the overstory trees ( $\geq 50 \mathrm{~cm}$ in diameter at breast height; see [46]). The two investigated primary forests of the Carpathian Mountains [17] showed no signs of silvicultural disturbance [7]. Rožok is a National Nature Reserve (NNR) in the Slovakian Republic near the Ukraine Border. The second primary forest Uholka is located in Uholka-ShyrokyLuh (Ukraine), which is part of the Carpathian Biosphere Reserve (CBR). In Rožok, the average age of mature trees was 180 to 230 years [47]. We assumed a conservative mean age of about 220 years for Rožok (see Table 2). The mean age of dominant trees in Uholka was estimated to be 350 years [21]. For details on the primary beech forests of Rožok and Uholka, the interested reader is referred to Kucbel et al. [20] and Commarmot et al. [19]. 


\subsection{Terrestrial Laser Scanning and Sampling Design}

We used terrestrial laser scanning to measure the three-dimensional structure of each stand. In order to collect data of forest stands in leaf-on condition, measurements were done in the vegetation period (May to August), with all species being fully foliaged. Within the framework of the Biodiversity Exploratories, scans were conducted in 2014. All other scans were taken in 2017 and 2018. All scans were conducted at wind speeds below $10 \mathrm{~m}^{-1}$ and during dry weather conditions.

Before scanning in the field, four sample plots were randomly placed in an area of about 20 hectares within each forest site using QGIS software (Quantum GIS Development Team 2017). Additionally, we selected a subset of seven sample plots from the repository of the Biodiversity Exploratories. Within the Biodiversity Exploratory project, an area of $45 \times 45 \mathrm{~m}$ was considered for data acquisition. For the data collection in 2017/2018, we scanned an area of $50 \times 50 \mathrm{~m}$. The scans were based on the multi-scan approach [48]. Before scanning, chessboard targets were distributed in order to enable a spatial co-registration. To cover the vegetation in detail and from multiple perspectives, $30-80$ scans were systematically distributed across the plot. However, the exact number and position of the scans depended on the understory density and heterogeneity. We conducted more scans in plots with dense understory compared to plots with lower understory density. Nevertheless, even with a large number of scans per plot, there is still the possibility that occlusion affected the measured spatial complexity, resulting in an underestimation of the real complexity. However, Ehbrecht et al. [26] showed that with more than 18 scans per plot $(40 \times 40 \mathrm{~m})$, a threshold that we always met, occlusion cannot be significantly reduced anymore.

The scans were performed with a Faro Focus 3D laser scanner (Faro Technologies Inc., Lake Mary, FL, USA). In the year 2018, additionally, the Faro Focus M70 (Faro Technologies Inc) was used, depending on which model was available. Before scanning, it was ensured that both scanners had the same scan settings and used identical standard filters during the scan process (Clear Contour- and Clear Sky-filter).

In the field, the scanners were placed on a tripod at breast height $(1.30 \mathrm{~m}$ above ground). Both instruments covered a field of view of $300^{\circ}$ (vertically) $\times 360^{\circ}$ (horizontally). During scanning, an angular resolution of $0.035^{\circ}$ was used, resulting in a resolution of 10,240 points per $360^{\circ}$.

All scans were imported into the Faro Scene Software (Faro Technologies Inc). Dark scan points (with low reflectance) and erroneous points (e.g., split beams) were eliminated using the software's standard filters. Then, all individual scans conducted within one plot were co-registered, so that at the end, one three-dimensional (3D) point cloud is representing one plot.

\subsection{Data Processing}

Then, raw point clouds were imported into Mathematica ${ }^{\circledR}$ software (Wolfram Research, Champaign, IL, USA). In order to normalize the spatial density of the point clouds, they were voxelized based on $20 \times 20 \times 20 \mathrm{~cm}$ voxels (volumetric pixels). We decided to choose this voxel size for several reasons. If the voxel size is chosen too small, it would be possible that occlusion effects result in artificial gaps in the voxel model. Additionally, tree trunks may appear as hollow cylinders instead of solid objects, which would lead to an underestimation of space filling by plant material [49]. While larger voxel sizes have proven to be a solid method to compensate occlusion, they can lead to an overestimation of the effective space filling, because smaller gaps are missed [26]. By using larger voxel sizes, there is also the risk that structural heterogeneity cannot be recorded in detail. Since we know that a voxel size of $20 \mathrm{~cm}$ side length is a trustful size in order to minimize occlusion effects and preserve detailed information on forest structure at the same time, we decided on this voxel length $[26,50]$.

Filled voxels contained at least one laser hit, whereas empty voxels had no laser hits. To exclude uneven terrain, we corrected the topography based on a digital terrain model calculated from the voxelized point cloud using the lowermost hits. Then, the ground-level height from the digital terrain model was used to calculate normalized heights for each voxel. To do so, each voxel was corrected 
with the terrain level height at the voxel's xy-position. Out of the voxelized, slope-corrected point clouds, we extracted a predefined extent $(40 \mathrm{~m} \times 40 \mathrm{~m} \times$ stand height). In order to reduce the influences of terrain points, shrubs, grasses, and dead wood on the data, we eliminated all voxels below $1 \mathrm{~m}$ stand height. The stand height of each individual 3D forest stand was defined as the uppermost height stratum, in which at least one voxel was present, and it was considered as 100\% (relative heights). The absolute stand height was defined as the $\mathrm{z}$-value of the highest voxel in the uppermost layer minus $1 \mathrm{~m}$.

To quantify the complexity of the forest structures, we used the box-dimension $\left(\mathrm{D}_{\mathrm{b}}\right)$ that is used to describe the fractal dimension of objects [28]. $\mathrm{D}_{\mathrm{b}}$ was calculated as the slope of the fitted straight line through a scatterplot of $\log (n)$ over $\log (1 / \mathrm{r})$. In this context, $\log ()$ is the natural $\log$ arithm and $n$ is the number of boxes with the size $r$ needed to enclose all points in a 3D point cloud. Details on this method when applied to trees or forest stands can be found in Seidel et al. [34] and Sarkar and Chaudhuri [51].

We calculated the $\mathrm{D}_{\mathrm{b}}$ for three horizontal forest strata of each $3 \mathrm{D}$ point cloud. Based on the classification of the International Union of Forest Research Organizations (IUFRO), we defined the lower stratum as the lowest 33\%, the middle stratum between $34 \%$ and $66 \%$, and the upper stratum from $67 \%$ to $100 \%$ of our predefined stand height $[52,53]$ (see Figure 2).

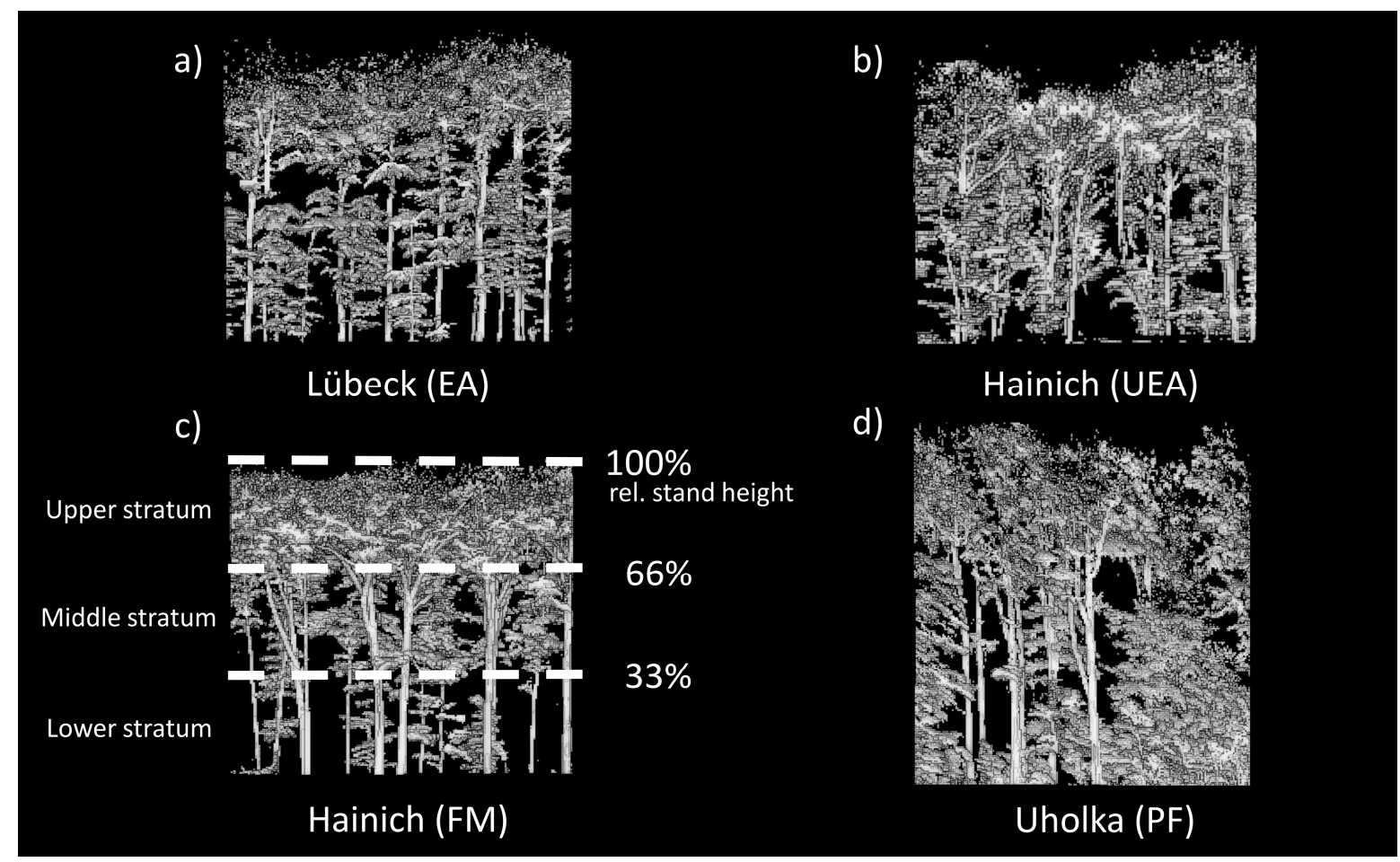

Figure 2. Side views of transects gained of voxelized $(20 \times 20 \times 20 \mathrm{~cm}) 3 \mathrm{D}$ forest stands representing different forest types: An even-aged (EA) forest stand in Lübeck (a), a managed uneven-aged (UEA) and formerly managed (FM) forest stand in Hainich $(\mathbf{b}, \mathbf{c})$ and an unmanaged primary forest (PF) in Uholka (d). The relative stand height (100\%) was defined as the uppermost stand stratum in which at least one voxel could be found. The three main forest strata were lower forest stratum $(\leq 33 \%$ of the relative stand height), middle forest stratum (34-66\% of the relative stand height), and the upper forest stratum $(67-100 \%$ of relative stand height).

To determine the density and spatial patterns of the vegetation, we imported the voxelized, slope-corrected 3D point clouds into the software R (version 3.4.2; R Development Core Team, 2017 Vienna, Austria). We divided each point cloud into 20 horizontal strata, each $5 \%$ of the total stand height in thickness. We used the relative space filling rSPf [\%] as a measure of density and calculated it for each stratum. The calculation of the rSPf [\%] was based on the method described in Juchheim et al. [48]. rSPf [\%] describes the percentage of space that is filled with voxels that contained vegetation hits. 
To calculate $\operatorname{rSPf}[\%]$, the volume of all filled voxels within a stratum was determined and set in relation to the stratum's total volume.

To describe spatial patterns of the vegetation, we calculated the Clark-Evans index (CE index) of aggregation [54] using the package ('spatstat'). Before the calculation, we projected the 20 horizontal strata onto a plane by setting the height value (z-value) of each voxel to zero (vertical projection). Subsequently, we extracted duplicate voxels. We used the index as a measure of horizontal point patterns of individual voxels in the area of the previously extracted horizontal strata. It is based on the distance from a voxel to its nearest neighbor and defined as:

$$
\mathrm{R}=\overline{\mathrm{r}} \mathrm{A} / \overline{\mathrm{r}} \mathrm{E}
$$

with $\overline{\mathrm{r}} \mathrm{A}$ being the mean observed distance from randomly selected voxel to their nearest neighbors and $\overline{\mathrm{r}} E$ being the expected mean distance between nearest neighbors, if a random distribution (Poisson distribution) is assumed. The ratio $R$ expresses the degree to which $\overline{\mathrm{r}} \mathrm{A}$ approaches or departs from $\overline{\mathrm{r}} \mathrm{A}$. $\mathrm{R}$ values range between 0 (maximum clumping) and 2.1491 (strictly regular, hexagonal pattern). Values equal to 1 indicate random voxel patterns. Based on this range, one can coarsely distinguish between clustered $(R<1)$ and more regular $(R>1)$ voxel patterns. To avoid edge bias on the aggregation index, the Donnelly edge correction was applied $[55,56]$.

\subsection{Statistics}

Statistical analyses were done with the software R, version 3.6.3 (R Development Core Team, 2020, Vienna, Austria). Before determining differences in $D_{b}$ for the different forest types, we tested for normal distribution and homogeneity of variance (Shapiro-Wilk test for normality; Levene test for homogeneity of variance). If the data met the conditions for parametric tests, we used the ANOVA to test for differences in $\mathrm{D}_{\mathrm{b}}$ between the different forest types. After applying the ANOVA, we used the Tukey HSD (honestly significant difference) test for post-hoc comparisons. In case normal distribution and homogeneity of variance could not be assumed, we used the non-parametric Kruskal-Wallis test to determine differences in $D_{b}$ for the different forest types. For post-hoc analysis, we applied the Wilcoxon rank sum test. We used a significance level of $p<0.05$ for all tests.

\section{Results}

\section{1. $D_{b}$ of the Lower, Middle, and Upper Forest Stratum of Differently Managed and Unmanaged Beech-Dominated Stands}

We found significant differences in $D_{b}$ of all three forest strata between the different forest types (see Figure $3 a-c$ ). The highest median of the $D_{b}$ was found in the lower forest stratum of the primary forests. It was significantly higher than those of the lower forest strata in the even-aged $(p=0.014)$ and formerly managed stands $(p<0.001)$, but equal to the uneven-aged stands $(p=0.139)$ (see Figure 3a). Considering the middle forest stratum, we found significant differences in $D_{b}$ between the managed even-aged and the formerly managed stands $(p<0.001)$ (see Figure $3 b$ ).

In the upper forest stratum, $\mathrm{D}_{\mathrm{b}}$ was significantly lower in the primary forests than in the even-aged $(p=0.0011)$ and formerly managed beech stands $(p=0.007)$, but we found no significant differences between the $D_{b}$ of the primary forests and the uneven-aged managed stands $(p=0.236)$ (see Figure 3c). We also observed that the $D_{b}$ of the upper forest stratum in the formerly managed stands did not differ significantly from the managed, even-aged beech stands $(p=0.887)$ (see Figure 3c). Compared to the even-aged stands, the uneven-aged stands showed significantly lower $D_{b}$ in the upper forest stratum $(p=0.012)$.

Considering the lower forest stratum of the managed even-aged stands, lowest $D_{b}$ was observed in the forest district Reinhausen (98 years) (see Table 2). Looking at the lower stratum of the formerly managed forests and the primary forests (both unmanaged forests), we observed increasing $D_{b}$ median values from the formerly managed stands (150-184 years) over Rožok (approximately 220 years) to 
Uholka (approximately 350 years) (see Table 2). Considering the unmanaged forests, Rožok showed highest $D_{b}$ in the middle forest stratum (see Table 2). For the upper forest stratum of the managed stands, highest $D_{b}$ was found in Lübeck (131 years) (see Table 2). Furthermore, we observed lowest $D_{b}$ for the upper stratum of the managed uneven-aged stands in Hainich-Dün (see Table 2). Looking at the upper forest stratum, there were decreasing $D_{b}$ median values from the formerly managed stands (150-184 years) over the primary forests Rožok (approximately 220 years) to Uholka (approximately 350 years) (see Table 2 ).

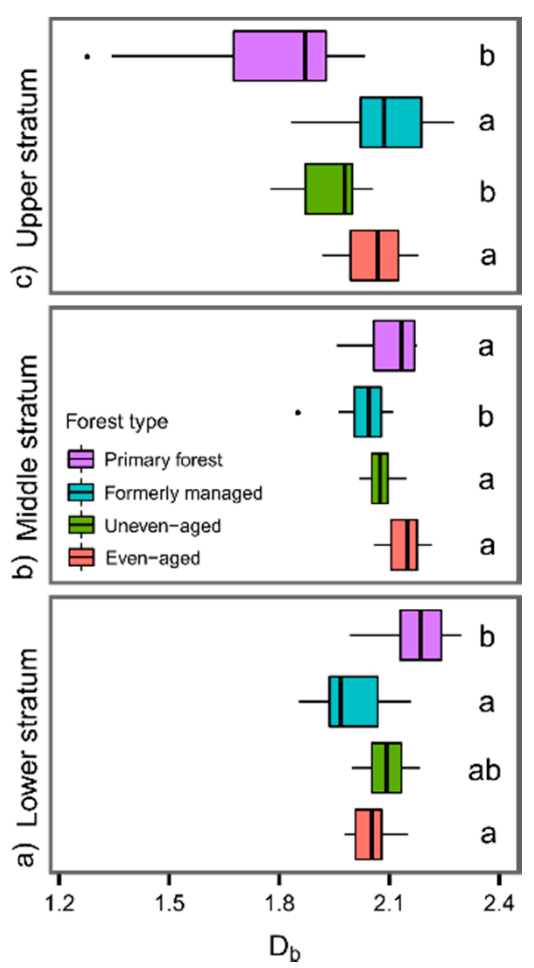

Figure 3. Box-and-whisker plots showing the box-dimension $\left(D_{b}\right)$ for the lower $(a)$, middle (b), and upper forest stratum (c) depending on the forest types. The different letters indicate significant differences between the different forest types at $p<0.05$. Sample sizes for the different forest types were even-aged managed (EA): $n=12$, uneven-aged managed (UEA): $n=8$, formerly managed (FM): $n=11$, and primary forest $(\mathrm{PF}): n=8$. Black horizontal lines indicate the median.

3.2. Spatial Patterns and Density of Vegetation in Differently Managed and Unmanaged Beech-Dominated Stands Within the Lower, Middle, and Upper Forest Strata

\subsubsection{Lower Forest Stratum ( $\leq 33 \%$ of Relative Stand Height)}

We found highest rSPf [\%] mean values within the lower forest stratum of the primary forest Uholka (rSPf $[\%]=9.55)$ and the uneven-aged forest stands in the Hainich-Dün region $(\mathrm{rSPf}[\%]=8.85)$ (see Table 2). The uneven-aged stands and the primary forests showed a tendency towards random to regular horizontal vegetation patterns within the entire lower forest stratum (CE index mean values $>1$, see Figure 4a), although Rožok showed lower mean values of the CE index when compared to Uholka (see Table 2). Compared to the primary forests and the uneven-aged stands, the even-aged managed and formerly managed stands showed, on average, clustered horizontal vegetation patterns within the entire lower forest stratum (see Figure 4a). 

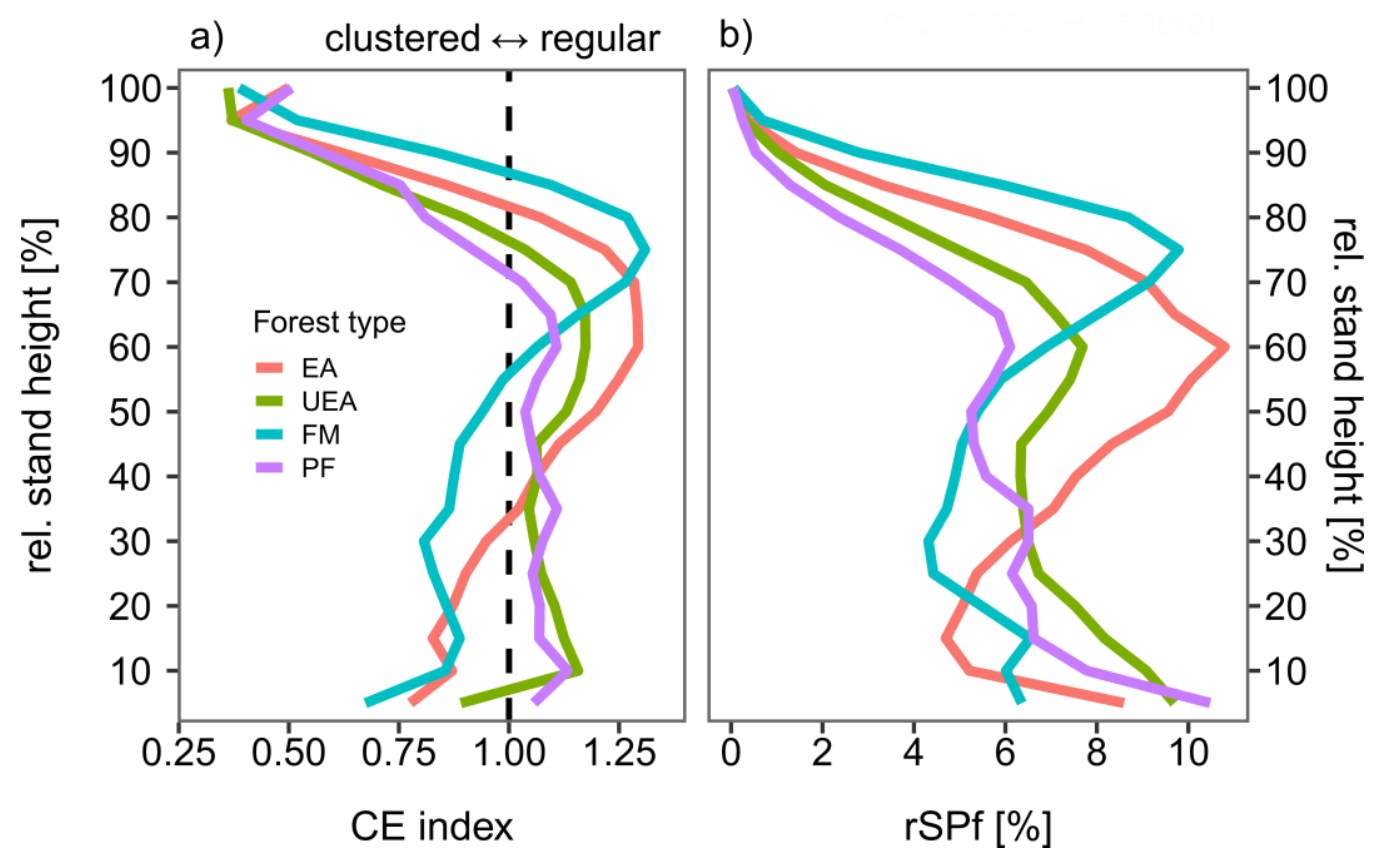

Figure 4. (a) Line plots showing the mean values of the Clark-Evans index (CE index) calculated for forest strata of $5 \%$ thickness each in the different forest types. Values $>1$ indicate regular spatial patterns, while values $<1$ tend to more clustered patterns. Values $=1$ indicate random patterns; (b) Line plots showing the mean values of relative space filling ( $\mathrm{rSPf} \%$ ) calculated for forest strata of $5 \%$ thickness each in the different forest types. Sample size per $5 \%$ height layer for different forest types was: even-aged (EA): $n=12$, uneven-aged (UEA): $n=8$, formerly managed (FM): $n=11$, and primary forest $(\mathrm{PF}): n=8$.

\subsubsection{Middle Forest Stratum (34-66\% of Rel. Stand Height)}

Within the middle layer, the lowest $\operatorname{rSPf}[\%]$ mean value was found in the primary forest Uholka (see Table 2). We found highest rSPf [\%] mean values in the even-aged stands (see Figure 4b; Table 2: Reinhausen $=9.69$ and Hann. Münden $=10.51$ ). Especially between $50 \%$ and $65 \%$ of total stand height, even-aged stands showed higher rSPf [\%] and mean values of CE index than the remaining forest types (see Figure $4 a, b$ ). Compared to the other forest types, the formerly managed stands showed lowest mean values of the CE index (see Figure 4a; Table 2). Up to a relative stand height of $50 \%$, they showed more clustered vegetation patterns (mean values $<1$ ) compared to the remaining forest types (mean values $>1$ ) (see Figure 4a).

\subsubsection{Upper Forest Stratum (67-100\% Rel. Stand Height)}

From $75 \%$ to $95 \%$ of relative stand height, rSPf [\%] and mean values of the CE index were constantly decreasing (see Figure $4 a, b$ ). The even-aged and formerly managed stands showed up to $90 \%$ of relative stand height, constantly higher rSPf [\%], and higher mean values of the CE index than the uneven-aged stands and primary forests (see Table 2). The primary forests showed a quite similar trend of rSPf [\%] and CE index as observed for the uneven-aged stands, with Uholka having the lowest rSPf [\%] mean values (see Figure 4a,b; Table 2).

\section{Discussion}

\subsection{Spatial Patterns of Structural Complexity of the Lower, Middle, and Upper Stratum of Different Forest Types}

The managed (EA, UEA) and unmanaged (FM, PF) forests considered here comprise different stand ages (see Table 1), resulting in a certain variability in $\mathrm{D}_{\mathrm{b}}, \mathrm{rSPf}[\%]$, and CE index (see Table 2). Within the lower, middle, and upper forest strata of the differently managed stands, we observed 
differences in the structural complexity, density, and horizontal distribution of plant material. In general, forest strata with a significantly higher $\mathrm{D}_{\mathrm{b}}$ (see Figure $3 \mathrm{a}-\mathrm{c}$ ) showed comparably high CE index and rSPf [\%] mean values (see Figure $4 a, b$ ). Therefore, it seems that forest strata with a higher $D_{b}$ are characterized by a high density and random to regular distribution of plant material. This pattern can be observed in the example of the lower stratum of the uneven-aged stands and primary forests (see Figure 3a; Figure 4a). In contrast, forest strata with a significantly lower $\mathrm{D}_{\mathrm{b}}$ (see Figure $3 \mathrm{a}-\mathrm{c}$ ) are also characterized by lower CE index and rSPf [\%] mean values (see Figure 4a,b). In this case, forest strata with a low $D_{b}$ were more likely to show clustered distribution patterns, as well as a lower occupation by plant material, as it can be exemplarily observed for the middle stratum of the formerly managed stands (see Figure 3b; Figure 4b). However, our observations are in line with the assumption that structural complexity is, to a certain degree, density-dependent [35,37], because the spatial arrangement of structure depends on the existence of plant material. This dependency can be pretty well observed in Figure 4, when comparing the vertical profile of rSPf [\%] and the CE index.

Canopy gaps have a direct impact on the spatial patterns of crown plant material [14]. In mature, even-aged stands, canopy gaps were created through target diameter harvests. Assuming that trees that have reached their target diameter are regularly distributed across the stand, canopy openings of the remaining canopy trees do also largely follow an even distribution $[4,46]$. Therefore, the remaining upper canopy plant material in the even-aged stands (70-80\% of relative stand height) tended to a more regular horizontal distribution (CE index mean values $>1$; see Figure $4 \mathrm{a}$ ).

Due to thinning from above, the remaining midstory trees of the managed even-aged stands were kept alive. This resulted in comparably high rSPf [\%] and CE index mean values in the middle forest stratum, as can be found in the forest districts Reinhausen and Hann. Münden (see Table 2). The positive effect of thinning from above on the rSPf [\%] of the middle forest stratum (50-60\% relative stand height) in beech-dominated stands was also observed by Juchheim et al. [48]. Due to a certain variation of tree heights and crown dimensions in the even-aged stands, plant material between $50 \%$ and $65 \%$ of relative stand height showed a more regular distribution pattern, while young regeneration growing in canopy gaps as well as stems of midstory trees appeared rather clustered in the lower layer (see Figure 4a, Table 2).

Compared to the even-aged stands, we observed a significantly lower $\mathrm{D}_{\mathrm{b}}$ for the upper forest stratum of the uneven-aged stands (see Figure 3c). One management goal in terms of creating an uneven-aged stand is a noticeable reduction of canopy closure [4]. Especially in beech-dominated uneven-aged forests, single to group selection is a common management tool to open up the canopy $[4,46]$. Interventions are mainly focused on the overstory trees $>50 \mathrm{~cm}$ diameter at breast height [46]. This would explain the lower rSPf [\%] mean values in the uneven-aged managed stands compared to the even-aged stands (see Figure $4 \mathrm{~b}$ ), resulting in a more clustered plant material of the upper canopy that is comparable to that of primary forests (see Figure 4a). The constant reduction of canopy closure in the upper layer of uneven-aged stands resulted in a regular vertical and horizontal distribution of dense plant material within the lower and middle forest stratum. We observed higher rSPf [\%] and CE index mean values up to $30 \%$ of relative stand height, compared to the majority of the even-aged stands (see Figure 4a,b).

Canopy gaps in unmanaged forests in Central Europe are caused by the mortality of single trees due to senescence, decay, and exogenous events, such as storms and snow falls [20,57,58]. In the upper forest stratum of the unmanaged forests under study, we found a significantly higher $D_{b}$ in the formerly managed stands than in the primary forests (see Figure 3c). The formerly managed beech stands showed a dense and regular distributed canopy structure between $75 \%$ and $90 \%$ of relative stand height (Figure $4 a, b$ ). These results can be explained by the fact that management in the formerly managed stands was ceased during their optimal phase, which the majority of the forests still seemed to be in (decay phase has not begun yet). Even if single trees might have collapsed or have been outcompeted by neighboring trees and left small gaps, these were quickly closed by the lateral crown expansion of neighboring beech trees due to their high crown plasticity [59-61]. The shading effect of 
the pronounced closure of the upper forest stratum led to a reduction in tree numbers in the midstory due to competition and a successive self-pruning of lower branches. This in turn resulted in lowest $D_{b}$ median for the middle forest stratum (see Figure 3b). We also observed a lower rSPf [\%] and lower CE index mean values compared to the primary forests (see Figure $4 a, b$ ). At the same time, a substantial regeneration layer could not develop yet, which was indicated by the low $D_{b}$ values for the lower forest stratum (see Figure 3a; Table 2). Therefore, trunks had the main influence on the horizontal distribution of plant material in the lower and middle stratum. For that reason, the formerly managed stands showed, on average, clustered patterns of plant material in the lower and middle forest stratum (see Figure 4a).

For the upper forest stratum of the unmanaged forests, we observed decreasing $D_{b}$ median values from the formerly managed stands (150-184 years) over the primary forest Rožok (approximately 220 years) to the primary forest Uholka (approximately 350 years) (see Table 1; Table 2). Compared to the formerly managed forests, the decay phase is more pronounced in old-growth forests and characterized by a larger number of small gaps $\left(<200 \mathrm{~m}^{2}\right)$ and a few larger gaps [62-67]. Stiers et al. [43] recorded small gaps for some of the primary forest stands investigated here $\left(<200 \mathrm{~m}^{2}\right)$. Since we observed lower mean values of rSPf [\%] in Uholka than in Rožok (see Table 2), we assume that the canopy of Uholkas' primary forests contains more and/or larger gaps. Therefore, one possible explanation for the low mean values of $D_{b}$ in Uholka's upper layer could be the absence of plant material as a result of decay. However, the upper stratum of primary forests is not always organized in a single stratum, but it is sometimes dominated by a few giant trees emerging from a more closed stratum underneath. The emergent layer is characterized by a lower space occupation compared to the layer underneath. This resulted in the low box-dimension values, which are, in extreme cases, close to 1 due to the presence of a few tree tops of giant trees reaching out of the "stand". Considering the other forest stands, the vertical layering of the upper stratum was more homogenous with no emergent trees.

Due to the large canopy openings, resulting in low rSPf [\%] values in the upper forest stratum in Uholka (see Table 2), pronounced understory vegetation could establish. This explains the high rSPf [\%] within the lower stratum (see Table 2). The different heights and crown dimensions of young and more advanced regeneration trees resulted in a pronounced vertical distribution of regularly distributed vegetation patches (see Figure $4 a, b$ ). The density of natural regeneration, as well as the heterogeneity of different heights of regeneration trees, resulted in a significantly higher $D_{b}$ for the lower forest stratum, compared to the one of the formerly managed forests (see Figure 3a). In addition, other understory attributes, such as shrub height [68] and understory species richness [69] were additional drivers for the high $D_{b}$ of Uholka's lower stratum. Commarmot et al. [19] found a rather sparse occupation of the middle forest stratum of the primary forest in Uholka. This result corresponds well with our observations. With a focus on the middle forest stratum, we found the lowest rSPf [\%] in Uholka (see Table 2). One explanation for this observation may be that suppressed beech strongly responds to increased light conditions, growing quickly through the midstory. When interpreting the space filling in the middle layer of Uholka, one has to consider the maximum height limit (in meter) of this stratum (see Table 2). The middle stratum of both primary forests ranged from about 15 to $30 \mathrm{~m}$. Due to this fact, the middle stratum of the investigated primary forest could be affected by a high age-induced mortality of mature trees.

In general, there is likely greater light availability in the middle and lower stratum with lower complexity in the upper stratum. However, a recent study conducted on the same sites as used in our study showed that light availability is not as important for the development of the understory of beech forest as reported for stands dominated by more light-demanding species [43]. 
Table 2. Box-dimension $\left(\mathrm{D}_{\mathrm{b}}\right)$, relative space filling (rSPf\%), Clark-Evans index (CE), and the height limits (m) of the lower, middle, and upper forest stratum of the forest stands in the different study sites (mean \pm standard deviation). Mean $\mathrm{D}_{\mathrm{b}}$ is defined as the arithmetic mean of the $\mathrm{D}_{\mathrm{b}}$ values calculated for the lower, middle, and upper forest stratum of each forest stand within the different study sites. Mean rSPf [\%] and mean CE is defined as the arithmetic mean of the rSPf [\%] and CE values calculated for $5 \%$ high forest strata within the lower, middle, and upper layer of each forest stand in the different study sites. Sample sizes for even-aged (EA) managed study sites were: Hann. Münden $(n=4)$, Lübeck $(n=4)$, and Reinhausen $(n=4)$. Sample sizes for uneven-aged (UEA) managed study sites were: Ebrach $(n=4)$, Hainich-Dün $(n=4)$. Sample sizes for formerly managed (FM) study sites were: Hainich-Dün $(n=7)$, Kellerwald $(n=4)$. Sample sizes for Primary forests (PF) were: Rožok $(n=4)$ and Uholka $(n=4)$.

\begin{tabular}{|c|c|c|c|c|c|c|c|c|c|c|c|c|c|}
\hline \multicolumn{6}{|c|}{ Lower Stratum } & \multicolumn{3}{|c|}{ Middle Stratum } & \multicolumn{5}{|c|}{ Upper Stratum } \\
\hline \multicolumn{2}{|c|}{ Study Site } & $D_{b}$ & rSPf $(\%)$ & $\mathrm{CE}$ & Height Limits (m) & $D_{b}$ & rSPf $(\%)$ & $\mathrm{CE}$ & Height Limits (m) & $D_{b}$ & rSPf (\%) & $\mathrm{CE}$ & Height Limits (m) \\
\hline \multicolumn{2}{|c|}{ Ebrach (UEA) } & $2.14 \pm 0.05$ & $7.04 \pm 1.80$ & $1.06 \pm 0.15$ & $\begin{array}{c}\text { Min: } 1 \\
\text { Max: } 12.1 \pm 0.6\end{array}$ & $2.10 \pm 0.04$ & $5.55 \pm 0.91$ & $1.07 \pm 0.07$ & $\begin{array}{c}\text { Min: } 12.1 \pm 0.6 \\
\text { Max: } 24.3 \pm 1.89\end{array}$ & $1.99 \pm 0.01$ & $2.41 \pm 2.24$ & $0.76 \pm 0.31$ & $\begin{array}{l}\text { Min: } 24.3 \pm 1.89 \\
\text { Max: } 35.7 \pm 2.15\end{array}$ \\
\hline \multirow{2}{*}{ Hainich } & (UEA) & $2.05 \pm 0.04$ & $8.85 \pm 1.37$ & $1.07 \pm 0.05$ & $\begin{array}{c}\text { Min: } 1 \\
\text { Max: } 11.15 \pm 0.93\end{array}$ & $2.05 \pm 0.02$ & $8.21 \pm 1.16$ & $1.16 \pm 0.08$ & $\begin{array}{l}\text { Min: } 11.15 \pm 0.93 \\
\text { Max: } 23.56 \pm 0.61\end{array}$ & $1.89 \pm 0.10$ & $2.83 \pm 1.50$ & $0.72 \pm 0.14$ & $\begin{array}{l}\text { Min: } 23.56 \pm 0.61 \\
\text { Max: } 33.9 \pm 2.75\end{array}$ \\
\hline & $(\mathrm{FM}))$ & $1.96 \pm 0.09$ & $4.61 \pm 2.22$ & $0.78 \pm 0.16$ & $\begin{array}{c}\text { Min: } 1 \\
\text { Max: } 11.73 \pm 0.3\end{array}$ & $2.01 \pm 0.08$ & $5.45 \pm 1.42$ & $0.92 \pm 0.13$ & $\begin{array}{c}\text { Min: } 11.73 \pm 0.3 \\
\text { Max: } 22.45 \pm 1.88\end{array}$ & $2.13 \pm 0.13$ & $6.28 \pm 2.04$ & $1.03 \pm 0.14$ & $\begin{array}{l}\text { Min: } 22.45 \pm 1.88 \\
\text { Max: } 35.8 \pm 0.92\end{array}$ \\
\hline \multicolumn{2}{|c|}{ Hann. Münden (EA) } & $2.05 \pm 0.05$ & $6.76 \pm 4.23$ & $0.87 \pm 0.15$ & $\begin{array}{c}\text { Min: } 1 \\
\text { Max: } 11.4 \pm 0.51\end{array}$ & $2.16 \pm 0.05$ & $\begin{array}{c}10.51 \pm \\
2.75\end{array}$ & $1.22 \pm 0.15$ & $\begin{array}{l}\text { Min: } 11.4 \pm 0.51 \\
\text { Max: } 22.9 \pm 1.09\end{array}$ & $2.07 \pm 0.05$ & $4.42 \pm 4.01$ & $0.8 \pm 0.41$ & $\begin{array}{c}\text { Min: } 22.9 \pm 1.09 \\
\text { Max: } 33.55 \pm 1.59\end{array}$ \\
\hline \multicolumn{2}{|c|}{ Kellerwald (FM) } & $2.06 \pm 0.10$ & $7.12 \pm 4.95$ & $0.89 \pm 0.26$ & $\begin{array}{c}\text { Min: } 1 \\
\text { Max: } 10.15 \pm 0.41\end{array}$ & $2.07 \pm 0.02$ & $6.51 \pm 1.60$ & $1.05 \pm 0.11$ & $\begin{array}{l}\text { Min: } 10.15 \pm 0.41 \\
\text { Max: } 20.5 \pm 0.82\end{array}$ & $2.01 \pm 0.12$ & $3.58 \pm 3.3$ & $0.86 \pm 0.34$ & $\begin{array}{l}\text { Min: } 20.5 \pm 0.82 \\
\text { Max: } 29.9 \pm 1.25\end{array}$ \\
\hline \multicolumn{2}{|c|}{ Lübeck (EA) } & $2.09 \pm 0.05$ & $6 \pm 2.39$ & $0.92 \pm 0.21$ & $\begin{array}{c}\text { Min: } 1 \\
\text { Max: } 11.85 \pm 0.71\end{array}$ & $2.10 \pm 0.05$ & $6.80 \pm 2.54$ & $1.08 \pm 0.19$ & $\begin{array}{l}\text { Min: } 11.85 \pm 0.71 \\
\text { Max: } 23.83 \pm 1.31\end{array}$ & $2.10 \pm 0.10$ & $4.62 \pm 4.16$ & $0.96 \pm 0.40$ & $\begin{array}{l}\text { Min: } 23.83 \pm 1.31 \\
\text { Max: } 35.15 \pm 2.16\end{array}$ \\
\hline \multicolumn{2}{|c|}{ Reinhausen (EA) } & $2.02 \pm 0.03$ & $4.77 \pm 2$ & $0.80 \pm 0.07$ & $\begin{array}{c}\text { Min: } 1 \\
\text { Max: } 11.6 \pm 0.49 \\
\end{array}$ & $2.17 \pm 0.02$ & $9.69 \pm 2.61$ & $1.22 \pm 0.17$ & $\begin{array}{c}\text { Min: } 11.6 \pm 0.49 \\
\text { Max: } 23.25 \pm 0.89\end{array}$ & $1.99 \pm 0.07$ & $2.79 \pm 3.08$ & $0.8 \pm 0.37$ & $\begin{array}{l}\text { Min: } 23.25 \pm 0.89 \\
\text { Max: } 34.15 \pm 1.48\end{array}$ \\
\hline \multicolumn{2}{|c|}{ Rožok (PF) } & $2.10 \pm 0.08$ & $5.14 \pm 3.38$ & $0.87 \pm 0.19$ & $\begin{array}{c}\text { Min: } 1 \\
\text { Max: } 14.5 \pm 0.48\end{array}$ & $2.15 \pm 0.03$ & $6.71 \pm 2.04$ & $1.11 \pm 0.17$ & $\begin{array}{l}\text { Min: } 14.5 \pm 0.48 \\
\text { Max: } 29.1 \pm 0.90\end{array}$ & $1.92 \pm 0.08$ & $2.57 \pm 2.88$ & $0.7 \pm 0.39$ & $\begin{array}{c}\text { Min: } 29.1 \pm 0.90 \\
\text { Max: } 42.85 \pm 1.43\end{array}$ \\
\hline \multicolumn{2}{|c|}{ Uholka (PF) } & $2.25 \pm 0.04$ & $9.55 \pm 2.61$ & $1.28 \pm 0.15$ & $\begin{array}{c}\text { Min: } 1 \\
\text { Max: } 15.3 \pm 0.5\end{array}$ & $2.05 \pm 0.10$ & $4.80 \pm 2.66$ & $1.07 \pm 0.24$ & $\begin{array}{c}\text { Min: } 15.3 \pm 0.5 \\
\text { Max: } 30.75 \pm 0.91\end{array}$ & $1.59 \pm 0.34$ & $1.15 \pm 1.57$ & $0.68 \pm 0.30$ & $\begin{array}{l}\text { Min: } 30.75 \pm 0.91 \\
\text { Max: } 45.3 \pm 1.35\end{array}$ \\
\hline
\end{tabular}




\subsection{Methodical Considerations}

In order to account for the different stand heights, we chose relative heights to ensure the comparability of the different forest strata. This approach was also chosen in order to avoid empty upper strata of forest stands that are lower in height, which would be the case for fixed strata heights.

The definition of the three major forest strata used in our study is based on the IUFRO classification, which was also used in several other studies $[63,70,71]$ : lower stratum $<1 / 3$ stand height; middle stratum 1/3-2/3 stand height; and upper stratum ( $>2 / 3$ stand height) [53]. In our study, the stand height was defined as the uppermost layer, where at least one voxel could be found.

To ensure the comparability of the results, we deliberately selected stands in the mature timber stage. The majority of the investigated forest stands were characterized by a quite similar stand height. For these stands (managed and formerly managed stands), the stand heights varied between a minimum of $29.9 \mathrm{~m}$ and a maximum of $35.8 \mathrm{~m}$ (see Table 2). Therefore, the forest strata of these stands showed a rather low variation in thickness. However, if there are forest stands, which are considerably higher than the remaining forest stands, the use of relative heights showed limitations [72]. In this study, the stand height of the investigated primary forests varied between 42.85 and $45.3 \mathrm{~m}$, which was due to the presence of emerging trees. As a result, the strata of the primary forests showed a higher thickness compared to the smaller stands. These limitations have to be considered when evaluating and interpreting results.

\section{Conclusions}

The main goal of the current study was to determine the spatial characteristics of structural complexity within differently managed and unmanaged beech-dominated forests.

Our study showed that terrestrial laser scanning data can be used to quantify the structural complexity of single forest stratums. The considered beech-dominated primary forests are characterized by a complex forest structure in the lower forest stratum, resulting in significantly higher $D_{b}$ values for the lower forest stratum, compared to the even-aged stands.

Furthermore, it was possible to identify differences in density and the spatial distribution of plant material within differently managed and unmanaged forest stands. Both primary forests studied here showed a random to regular distribution of plant material within the lower stratum and middle forest stratum, but on average a lower space occupation for the middle stratum compared to the managed forest stands. This finding may have implications for the forest management. Our results clearly showed that management for uneven-aged stands leads to a quite similar spatial distribution of plant material, as observed for the primary forests. Management in beech-dominated forest that aims for increased structural complexity (taking primary forests as a reference) could focus on a promotion of complex understory structures, which can be achieved by creating larger canopy openings through single and group cuttings and the subsequent establishment of regeneration. Additionally, the reduction of vegetation density within the middle forest stratum could be considered.

Author Contributions: Conceptualization, K.W., D.S., M.E. and P.A.; methodology, K.W., D.S.; validation, K.W., C.A., D.S., M.E. and P.A.; resources, C.A., D.S.; data curation, K.W., M.S.; writing-Original draft preparation, K.W.; writing-Review and editing, K.W., C.A., D.S., M.E. and P.A.; visualization, K.W.; supervision, C.A., D.S., M.E. and P.A.; funding acquisition, C.A., D.S. and P.A. All authors have read and agreed to the published version of the manuscript.

Funding: Erich Ritter-Foundation (T0021/29427/2017) has mainly funded the research project. Furthermore, parts of the work were funded by the German Science Foundation (grant SE2383/5-1), as well as Priority Program 1374 "Infrastructure-Biodiversity-Exploratories" (grant numbers Am 149/16-2) and research grants granted to Dominik Seidel (Se 2383/1-1).

Acknowledgments: We thank Achim Frede, Axel Pampe, Bernd Schock, Knut Sturm, Martin Schafhirt, Myroslav Kabal, Peter Jaloviar, Sabine Steinhoff, Stanislav Kucbel, Thomas Schmidt-Langenhorst, Torsten Welle, Ulrich Mergner, Vasyl Lavnyy, and Yuriy Berkela, for helping us in selecting suitable plots. We are thankful to the Carpathian Biosphere Reserve (CBR), the administration of the National Park Poloniny and the environmental protection office in Presov for granting permission to access primary forests in Slovakia and Ukraine. 
Conflicts of Interest: The authors declare no conflict of interest.

\section{References}

1. Brang, P.; Spathelf, P.; Larsen, J.B.; Bauhus, J.; Boncina, A.; Chauvin, C.; Drössler, L.; García-Güemes, C.; Heiri, C.; Kerr, G.; et al. Suitability of close-to-nature silviculture for adapting temperate European forests to climate change. Forestry 2014, 87, 492-503. [CrossRef]

2. Messier, C.C.; Puettmann, K.J.; Coates, K.D. Managing Forests as Complex Adaptive Systems: Building Resilience to the Challenge of Global Change; Routledge: Abigdon, UK, 2013; pp. 187-214.

3. Puettmann, K.J.; Coates, K.D.; Messier, C.C. A Critique of Silviculture: Managing for Complexity; Island Press: Washington, DC, USA, 2009; pp. 107-108.

4. Schütz, J.-P. Silvicultural tools to develop irregular and diverse forest structures. Forestry 2002, 75, 329-337. [CrossRef]

5. Gadow, K.; Zhang, C.Y.; Wehenkel, C.; Pommerening, A.; Corral-Rivas, J.; Korol, M.; Myklush, S.; Hui, G.Y.; Kiviste, A.; Zhao, X.H. Forest structure and diversity. In Continuous Cover Forestry; Pukkala, T., von Gadow, K., Eds.; Springer: Dordrecht, The Netherlands, 2012; Volume 23, pp. 29-83.

6. Kint, V.; Robert, D.W.; Noël, L. Evaluation of sampling methods for the estimation of structural indices in forest stands. Ecol. Model. 2004, 180, 461-476. [CrossRef]

7. Brang, P. Virgin forests as a knowledge source for central European silviculture: Reality or myth? For. Snow Landsc. Res. 2005, 79, 19-32.

8. Gustafsson, L.; Baker, S.C.; Bauhus, J.; Beese, W.J.; Brodie, A.; Kouki, J.; Lindenmayer, D.B.; Lõhmus, A.; Pastur, G.M.; Messier, C.; et al. Retention Forestry to Maintain Multifunctional Forests: A World Perspective. BioScience 2012, 62, 633-645. [CrossRef]

9. Pommerening, A. Approaches to quantifying forest structures. Forestry 2002, 75, 305-324. [CrossRef]

10. Glatthorn, J.; Feldmann, E.; Pichler, V.; Hauck, M.; Leuschner, C. Biomass Stock and Productivity of Primeval and Production Beech Forests: Greater Canopy Structural Diversity Promotes Productivity. Ecosystems 2017, 110, 106. [CrossRef]

11. Gough, C.M.; Atkins, J.W.; Fahey, R.T.; Hardiman, B.S. High rates of primary production in structurally complex forests. Ecology 2019, 100, e02864. [CrossRef]

12. Pretzsch, H.; Biber, P.; Uhl, E.; Dauber, E. Long-term stand dynamics of managed spruce-fir-beech mountain forests in Central Europe: Structure, productivity and regeneration success. Forestry 2015, 88, 407-428. [CrossRef]

13. Ellison, A.M.; Bank, M.S.; Clinton, B.D.; Colburn, E.A.; Elliott, K.; Ford, C.R.; Foster, D.R.; Kloeppel, B.D.; Knoepp, J.D.; Lovett, G.M.; et al. Loss of foundation species: Consequences for the structure and dynamics of forested ecosystems. Front. Ecol. Environ. 2005, 3, 479-486. [CrossRef]

14. Franklin, J.F.; van Pelt, R. Spatial Aspects of Structural Complexity in Old-Growth Forests. J. For. 2004, 102, 22-28. [CrossRef]

15. Ehbrecht, M.; Schall, P.; Ammer, C.; Fischer, M.; Seidel, D. Effects of structural heterogeneity on the diurnal temperature range in temperate forest ecosystems. For. Ecol. Manag. 2019, 432, 860-867. [CrossRef]

16. Parker, G.G.; Harmon, M.E.; Lefsky, M.A.; Chen, J.; van Pelt, R.; Weis, S.B.; Thomas, S.C.; Winner, W.E.; Shaw, D.C.; Frankling, J.F. Three-dimensional Structure of an Old-growth Pseudotsuga-Tsuga Canopy and Its Implications for Radiation Balance, Microclimate, and Gas Exchange. Ecosystems 2004, 7, 440-453. [CrossRef]

17. Sabatini, F.M.; Burrascano, S.; Keeton, W.S.; Levers, C.; Lindner, M.; Pötzschner, F.; Verkerk, P.J.; Bauhus, J.; Buchwald, E.; Chaskovsky, O.; et al. Where are Europe's last primary forests? Divers. Distrib. 2018, 24, 1426-1439. [CrossRef]

18. Bauhus, J.; Puettmann, K.; Messier, C. Silviculture for old-growth attributes. For. Ecol. Manag. 2009, 258, 525-537. [CrossRef]

19. Commarmot, B. Structures of virgin and managed beech forests in Uholka (Ukraine) and Sihlwald (Switzerland): A comparative study. For. Snow Landsc. Res. 2005, 79, 45-56.

20. Kucbel, S.; Jaloviar, P.; Saniga, M.; Vencurik, J.; Klimaš, V. Canopy gaps in an old-growth fir-beech forest remnant of Western Carpathians. Eur. J. For. Res. 2010, 129, 249-259. [CrossRef]

21. Trotsiuk, V.; Hobi, M.L.; Commarmot, B. Age structure and disturbance dynamics of the relic virgin beech forest Uholka (Ukrainian Carpathians). For. Ecol. Manag. 2012, 265, 181-190. [CrossRef] 
22. Zenner, E.K.; Hibbs, D.E. A new method for modeling the heterogeneity of forest structure. For. Ecol. Manag. 2000, 129, 75-87. [CrossRef]

23. Witté, I.; Kneeshaw, D.; Messier, C. Do partial cuts create forest complexity? A new approach to measuring the complexity of forest patterns using photographs and the mean information gain. For. Chron. 2013, 89, 340-349. [CrossRef]

24. Du Preez, C. A new arc-chord ratio (ACR) rugosity index for quantifying threedimensional landscape structural complexity. Lands. Ecol. 2015, 30, 181-192. [CrossRef]

25. Atkins, J.W.; Bohrer, G.; Fahey, R.T.; Hardiman, B.S.; Morin, T.H.; Stovall, A.E.L.; Zimmerman, N.; Gough, C.M. Quantifying vegetation and canopy structural complexity from terrestrial LiDAR data using the forestr $\mathrm{r}$ package. Methods Ecol. Evol. 2018, 9, 2057-2066. [CrossRef]

26. Ehbrecht, M.; Schall, P.; Juchheim, J.; Ammer, C.; Seidel, D. Effective number of layers: A new measure for quantifying three-dimensional stand structure based on sampling with terrestrial LiDAR. For. Ecol. Manag. 2016, 380, 212-223. [CrossRef]

27. Seidel, D.; Ehbrecht, M.; Puettmann, K. Assessing different components of three-dimensional forest structure with single-scan terrestrial laser scanning: A case study. For. Ecol. Manag. 2016, 381, 196-208. [CrossRef]

28. Mandelbrot, B.B. Stochastic models for the Earth's relief, the shape and the fractal dimension of the coastlines, and the number-area rule for islands. Proc. Natl. Acad. Sci. USA 1975, 72, 3825-3828. [CrossRef]

29. Boudon, F.; Godin, C.; Pradal, C.; Puech, O.; Sinoquet, H. Estimating the fractal dimension of plants using the two-surface method: An analysis based on 3D-digitized tree foliage. Fractals 2011, 14, 149-163. [CrossRef]

30. Dutilleul, P.; Han, L.; Valladares, F.; Messier, C. Crown traits of coniferous trees and their relation to shade tolerance can differ with leaf type: A biophysical demonstration using computed tomography scanning data. Front. Plant Sci. 2015, 6, 172. [CrossRef]

31. Jonckheere, I.; Nackaerts, K.; Muys, B.; van Aardt, J.; Coppin, P. A fractal dimension-based modelling approach for studying the effect of leaf distribution on LAI retrieval in forest canopies. Ecol. Model. 2006, 197, 179-195. [CrossRef]

32. Zhu, J.; Wang, X.; Chen, J.; Huang, H.; Yang, X. Estimating fractal dimensions of tree crowns in 3-D space based on structural relationships. For. Chron. 2014, 90, 177-183. [CrossRef]

33. Dorji, Y.; Annighöfer, P.; Ammer, C.; Seidel, D. Response of Beech (Fagus sylvatica L.) Trees to Competition-New Insights from Using Fractal Analysis. Remote Sens. 2019, 11, 2656. [CrossRef]

34. Seidel, D. A holistic approach to determine tree structural complexity based on laser scanning data and fractal analysis. Ecol. Evol. 2018, 102, 3. [CrossRef] [PubMed]

35. Seidel, D.; Ehbrecht, M.; Annighöfer, P.; Ammer, C. From tree to stand-level structural complexity-Which properties make a forest stand complex? Agric. For. Meteorol. 2019, 278, 107699. [CrossRef]

36. Zemp, D.C.; Ehbrecht, M.; Seidel, D.; Ammer, C.; Craven, D.; Erkelenz, J.; Irawan, B.; Sundawati, L.; Hölscher, D.; Kreft, H. Mixed-species tree plantings enhance structural complexity in oil palm plantations. Agric. Ecosyst. Environ. 2019, 283, 106564. [CrossRef]

37. Ehbrecht, M.; Schall, P.; Ammer, C.; Seidel, D. Quantifying stand structural complexity and its relationship with forest management, tree species diversity and microclimate. Agric. For. Meteorol. 2017, 242, 1-9. [CrossRef]

38. Willim, K.; Stiers, M.; Annighöfer, P.; Ammer, C.; Ehbrecht, M.; Kabal, M.; Stillhard, J.; Seidel, D. Assessing understory complexity in beech-dominated Forests (Fagus sylvatica L.)-from managed to primary forests. Sensors 2019, 19, 1684. [CrossRef]

39. Stiers, M.; Willim, K.; Seidel, D.; Ehbrecht, M.; Kabal, M.; Ammer, C.; Annighöfer, P. A quantitative comparison of the structural complexity of managed, lately unmanaged and primary European beech (Fagus sylvatica L.) forests. For. Ecol. Manag. 2018, 430, 357-365. [CrossRef]

40. Camarretta, N.; Harrison, P.A.; Bailey, T.; Potts, B.; Lucieer, A.; Davidson, N.; Hunt, M. Monitoring forest structure to guide adaptive management of forest restoration: A review of remote sensing approaches. New For. 2019, 18, 305. [CrossRef]

41. Kottek, M.; Grieser, J.; Beck, C.; Rudolf, B.; Rubel, F. World Map of the Köppen-Geiger climate classification updated. Meteorol. Z. 2006, 15, 259-263. [CrossRef]

42. Entscheidungshilfen zur Behandlung und Entwicklung von Buchenbeständen. Available online: https://www.nw-fva.de/fileadmin/user_upload/Verwaltung/Publikationen/Merkblaetter/Bu_Nds_Entschei dungshilfen_zur_Behandlung_und_Entwicklung_von_Buchenbestaenden.pdf (accessed on 30 July 2018). 
43. Stiers, M.; Willim, K.; Seidel, D.; Ammer, C.; Kabal, M.; Stillhard, J.; Annighöfer, P. Analyzing Spatial Distribution Patterns of European Beech (Fagus sylvatica L.) Regeneration in Dependence of Canopy Openings. Forests 2019, 10, 637. [CrossRef]

44. Fischer, M.; Bossdorf, O.; Gockel, S.; Hänsel, F.; Hemp, A.; Hessenmöller, D.; Korte, G.; Nieschulze, J.; Pfeiffer, S.; Prati, D.; et al. Implementing large-scale and long-term functional biodiversity research: The Biodiversity Exploratories. Basic Appl. Ecol. 2010, 11, 473-485. [CrossRef]

45. Bartsch, N.; von Lüpke, B.; Röhrig, E. Waldbau auf ökologischer Grundlage; Eugen Ulmer KG: Stuttgart, Germany, 2006; p. 549.

46. Schall, P.; Gossner, M.M.; Heinrichs, S.; Fischer, M.; Boch, S.; Prati, D.; Jung, K.; Baumgartner, V.; Blaser, S.; Böhm, S.; et al. The impact of even-aged and uneven-aged forest management on regional biodiversity of multiple taxa in European beech forests. J. Appl. Ecol. 2018, 109, 267-278. [CrossRef]

47. Korpel', S. Die Urwälder der Westkarpaten; Gustav Fischer Verlag: Stuttgart, Germany, 1995; pp. $132-148$.

48. Juchheim, J.; Ammer, C.; Schall, P.; Seidel, D. Canopy space filling rather than conventional measures of structural diversity explains productivity of beech stands. For. Ecol. Manag. 2017, 395, 19-26. [CrossRef]

49. Seidel, D.; Leuschner, C.; Scherber, C.; Beyer, F.; Wommelsdorf, T.; Cashman, M.J.; Fehrmann, L. The relationship between tree species richness, canopy space exploration and productivity in a temperate broad-leaf mixed forest. For. Ecol. Manag. 2013, 310, 366-374. [CrossRef]

50. Béland, M.; Widlowski, J.L.; Fournier, R.A. A model for deriving voxel-level tree leaf area density estimates from ground-based LiDAR. Environ. Model. Softw. 2014, 51, 184-189. [CrossRef]

51. Sarkar, N.; Chaudhuri, B.B. An efficient differential box-counting approach to compute fractal dimension of image. IEEE Trans. Syst. Man Cybern. 1994, 24, 115-120. [CrossRef]

52. Stinglwagner, G.; Haseder, I.; Erlbeck, R. Das Kosmos Wald \& Forst-Lexikon; Kosmos: Stuttgart, Germany, 2009; p. 76.

53. Leibundgut, H. Empfehlungen für die Baumklassenbildung und Methodik bei Versuchen über die Wirkung von Waldpflegemassnahmen; IUFRO-Congr: Oxford, UK, 1956; pp. 92-94.

54. Clark, P.J.; Evans, F.C. Distance to Nearest Neighbor as a Measure of Spatial Relationships in Populations. Ecology 1954, 35, 445-453. [CrossRef]

55. Donnelly, K. Simulations to determine the variance and edge-effect of total nearest neighbour distance. In Simulation Studies in Archaeology; Hodder, I., Ed.; Cambridge University Press: Cambridge, UK; New York, NY, USA, 1978; pp. 91-95.

56. Pommerening, A.; Stoyan, D. Edge-correction needs in estimating indices of spatial forest structure. Can. J. For. Res. 2006, 36, 1723-1739. [CrossRef]

57. Nagel, T.A.; Svoboda, M.; Kobal, M. Disturbance, life history traits, and dynamics in an old-growth forest landscape of southeastern Europe. Ecol. Appl. 2014, 24, 663-679. [CrossRef]

58. Schelhaas, M.J.; Nabuurs, G.J.; Schuck, A. Natural disturbances in the European forests in the 19th and 20th centuries. Glob. Chang. Biol. 2003, 9, 1620-1633. [CrossRef]

59. Emborg, J.; Christensen, M.; Heilmann-Clausen, J. The structural dynamics of Suserup Skov, a near-natural temperate deciduous forest in Denmark. For. Ecol. Manag. 2000, 126, 173-189. [CrossRef]

60. Feldmann, E.; Drößler, L.; Hauck, M.; Kucbel, S.; Pichler, V.; Leuschner, C. Canopy gap dynamics and tree understory release in a virgin beech forest, Slovakian Carpathians. For. Ecol. Manag. 2018, 415-416, 38-46. [CrossRef]

61. Schröter, M.; Härdtle, W.; von Oheimb, G. Crown plasticity and neighborhood interactions of European beech (Fagus sylvatica L.) in an old-growth forest. Eur. J. For. Res. 2012, 131, 787-798. [CrossRef]

62. Drößler, L. Struktur und Dynamik von zwei Buchenurwäldern in der Slowakei. Ph.D. Thesis, Georg-August-University, Göttingen, Germany, 2006.

63. Hobi, M.L.; Ginzler, C.; Commarmot, B.; Bugmann, H. Gap pattern of the largest primeval beech forest of Europe revealed by remote sensing. Ecosphere 2015, 6, art76. [CrossRef]

64. Hobi, M.L.; Commarmot, B.; Bugmann, H. Pattern and process in the largest primeval beech forest of Europe (Ukrainian Carpathians). J. Veg. Sci. 2015, 26, 323-336. [CrossRef]

65. Kenderes, K.; Mihók, B.; Standovár, T. Thirty years of gap dynamics in a central european beech forest reserve. Forestry 2008, 81, 111-123. [CrossRef]

66. Meyer, P.; Vath, T.; Burghard, V.L. Die Struktur albanischer Rotbuchen-Urwälder - Ableitungen für eine naturnahe Buchenwirtschaft. Forstwissenschaftliches Centralblatt 2003, 122, 47-58. [CrossRef] 
67. Nagel, T.A.; Svoboda, M.; Rugani, T.; Diaci, J. Gap regeneration and replacement patterns in an old-growth Fagus-Abies forest of Bosnia-Herzegovina. Plant Ecol. 2010, 208, 307-318. [CrossRef]

68. Berger, A.L.; Puettmann, K. Overstory Composition and Stand Structure Influence Herbaceous Plant Diversity in the Mixed Aspen Forest of Northern Minnesota. Am. Nat. 2000, 143, 111-125. [CrossRef]

69. Sullivan, T.P.; Sullivan, D.S.; Lindgren, P.M. Stand structure and small mammals in young lodgepole pine forest: 10-year results after thinning. Ecol. Appl. 2001, 11, 1151-1173. [CrossRef]

70. Von Oheimb, G.; Westphal, C.; Tempel, H.; Härdtle, W. Structural pattern of a near-natural beech forest (Fagus sylvatica) (Serrahn, North-east Germany). For. Ecol. Manag. 2005, 212, 253-263. [CrossRef]

71. Rugani, T.; Diaci, J.; Hladnik, D. Gap Dynamics and Structure of Two Old-Growth Beech Forest Remnants in Slovenia. PLoS ONE 2012, 8, e52641. [CrossRef] [PubMed]

72. Parker, G.G.; Brown, M.J. Forest canopy stratification-Is it useful? Am. Nat. 2000, 155, 473-484. [CrossRef] [PubMed]

(C) 2020 by the authors. Licensee MDPI, Basel, Switzerland. This article is an open access article distributed under the terms and conditions of the Creative Commons Attribution (CC BY) license (http://creativecommons.org/licenses/by/4.0/). 